Abstract PWE-201 Table 1

\begin{tabular}{llll}
\hline $\begin{array}{l}\text { Polypectomy } \\
\text { technique }\end{array}$ & $\begin{array}{l}\text { Number of } \\
\text { polyps removed }\end{array}$ & $\begin{array}{l}\text { Range of } \\
\text { polyp size }(\mathbf{m m})\end{array}$ & $\begin{array}{l}\text { Gastroenterologist: } \\
\text { surgeon }\end{array}$ \\
\hline Cold biopsy & 10 & $2-8$ & $7: 3$ \\
Cold snare & 17 & $3-9$ & $16: 1$ \\
EMR & 4 & $2-15$ & $4: 0$ \\
Hot biopsy & 3 & $1-5$ & $0: 3$ \\
Hot snare & 5 & $2-12$ & $2: 3$ \\
\hline
\end{tabular}

Methods The aim was to assess the method of colonic polypectomy used in comparison to recommendations by all endoscopists at our district general hospital. A prospective assessment of polypectomy technique from the right colon was performed from a district general hospital in North London over 6 months from October 2009. Endoscopy nursing staff were asked to document site and method used to remove and retrieve the polyp. Patients were identified prospectively from nursing records of the procedures from the endoscopy registry book and then the polypectomy technique used was scrutinised.

Results A total of 39 polypectomies from the right colon were documented during the 6 months study period, with 29 completed by a Gastroenterologist and 10 by a surgical colleague. The size of polypectomy varied between $2 \mathrm{~mm}$ and $15 \mathrm{~mm}$. In the Cold biopsy group, there were 3 polyps $>6 \mathrm{~mm}(6,7$ and $8 \mathrm{~mm})$ in size and these three were completed by a surgeon. In the Cold Snare group, there was 1 polyp $>7 \mathrm{~mm}(9 \mathrm{~mm})$ in size and this was removed by a surgeon by this method. In the Hot biopsy group, there were 3 polyps $(1,4,5 \mathrm{~mm})$ in size and all were removed by a surgeon with this technique.

Conclusion Our results show that there are varying techniques and methods used to excise polyps from the right colon. Despite increasing awareness of the thinness of the right colonic wall and hence increase risk of transmural thermal injury associated with hot biopsy this continues to be performed, in our study by surgical colleagues only. Despite cold biopsy technique likely to leave behind residual tissue, it continues to be used for polyps up to $8 \mathrm{~mm}$ in our study. For the cold snare technique guidance recommends use for polyps up to $7 \mathrm{~mm}$ to reduce risk of bleeding yet, in our study one cold snare was carried out for a $9 \mathrm{~mm}$ polyp. More awareness is required in the appropriate polypectomy technique for right sided polyps to improve efficacy.

Competing interests None declared.

\section{PWE-202 FEASIBILITY, SAFETY AND OUTCOMES OF AN ENDOSCOPIC SUBMUCOSAL DISSECTION SERVICE IN A UK SETTING}

doi:10.1136/gutjnl-2012-302514d.202

S Tholoor, ${ }^{*}$ P Basford, R Bhattacharyya, P Bhandari. Portsmouth Hospitals NHS Trust, Portsmouth, UK

Introduction Endoscopic Submucosal Dissection (ESD) is an established treatment of early gastrointestinal neoplasia in Japan. It carries a greater risk of complications than conventional EMR. Use and experience of ESD in the west is limited with most centres having only performed small numbers of cases. We aim to evaluate the outcomes of ESD service in our centre.

Methods Upper and Lower Gastrointestinal Endoscopic Resections database was evaluated to identify patients who underwent ESD and their demographics, histology, techniques, complications and outcomes were analysed.

Results Upper Gastrointestinal: 25 ESD were performed in 23 patients between 2006 and 2011 (11 males). Mean age was 61.5 years. 14/25 involved en bloc ESD (where a circumferential incision is made to remove the whole lesion) and 11/25 involved a hybrid technique (where a circumferential incision is made followed by resection using a snare). $2 / 25$ perforations occurred, both managed with endoscopic clips requiring no surgical intervention. 22/25 procedures were completed successfully. In $2 / 25$, lesions were unable to be fully resected and $1 / 25$ was abandoned due to perforation. Due to advanced histology, four proceeded to radical or palliative treatment. Colonic: 66 patients underwent ESD between 2006 and 2011 (21 males). Mean age was 68.5 years. 43/66 had enbloc ESD and 13/ 66 a hybrid procedure. 14/66 was in the right colon and 52/66 in the left colon. 24 lesions were LST-G, 8 were LST-NG and six were unspecified LST. Bleeding occurred in four cases (three delayed) all treated endosopically. Perforation occurred in four cases, only one required surgery and the rest ere managed with endoscopic clips. 4/66 had incomplete primary resection (one had perforation requiring surgery). 4/66 had recurrence requiring further sessions. 2/66 patients required curative surgery due to advanced histology.

Conclusion (1) ESD service is feasible, safe and effective in a UK setting. (2) Our data demonstrates that ESD can be used to treat a wide variety of lesions through out the gut. (3) Perforation remains a significant risk but effective clipping technique can avoid the need for surgery. (4) ESD should be centralised to high volume expert centres to achieve good outcomes and establish training programmes.

Competing interests None declared.

Abstract PWE-202 Table 1

\begin{tabular}{|c|c|c|c|c|c|c|c|}
\hline & Cancers/dysplasia & Submucosal/others & Curative resection & Recurrence & Bleeding & Perforation & Surgery \\
\hline $\begin{array}{l}\text { Oesophagus } \\
10\end{array}$ & $\begin{array}{l}7 \\
\text { Barrett's } \\
\text { LGD: } 2, \text { HGD: } 1 \\
\text { SM2/3: } 3 \\
\text { SCC: } 1\end{array}$ & $\begin{array}{l}3 \\
\text { GIST: } 1 \\
\text { Leiomyoma: } 1 \\
\text { Papilloma: } 1\end{array}$ & $8 / 10(80 \%)$ & 0 & 0 & $1 / 10(10 \%)$ & $\begin{array}{l}4 / 9(44 \%) \\
\text { All curative }\end{array}$ \\
\hline $\begin{array}{l}\text { Stomach } \\
14\end{array}$ & $\begin{array}{l}\text { IMC: } 2 \text { HGD: } 3 \\
\text { LGD: } 2 \\
\text { Hyperplastic: } 1 \\
\text { IFP: } 1\end{array}$ & $\begin{array}{l}5 \\
\text { Carcinoid: } 4 \\
\text { Lipoma: } 1\end{array}$ & $13 / 14(94 \%)$ & 0 & 0 & $1 / 14(0.7 \%)$ & \\
\hline $\begin{array}{l}\text { Duodenum } \\
1\end{array}$ & $\begin{array}{l}\text { Adenoma } \\
\text { LGD: } 1\end{array}$ & & $1 / 1(100 \%)$ & 0 & 0 & & \\
\hline $\begin{array}{l}\text { Colon } \\
\text { Total: } 66 \\
\text { R: } 14(21 \%) \\
\text { L: } 52(79 \%)\end{array}$ & $\begin{array}{l}\text { Morphology: } \\
\text { LST: } 38 \\
\text { Sessile: } 25 \\
\text { Flat: } 3 \\
\text { Histology: } \\
\text { SM1:2 SM2:2 } \\
\text { IMC:1 HGD:15 } \\
\text { LGD: } 46\end{array}$ & 0 & $62 / 66(94 \%)$ & $4 / 66(6 \%)$ & $4 / 66(6 \%)$ & $4 / 66(6 \%)$ & $\begin{array}{l}2 / 66(3 \%) \\
1 \text { curative } \\
1 \text { for perforation }\end{array}$ \\
\hline
\end{tabular}

